\title{
Clinical pharmacology of infusion fluids
}

\author{
Robert G. Hahn
}

\section{Linköping University Post Print}

Tweet

N.B.: When citing this work, cite the original article.

Original Publication:

Robert G. Hahn , Clinical pharmacology of infusion fluids, 2012, Acta Medica Lituanica, (19), 3.

Licencee: Lithuanian Academy of Sciences

http://www.Imaleidykla.lt/ojs/index.php/actamedicalituanica/index

Postprint available at: Linköping University Electronic Press

http://urn.kb.se/resolve?urn=urn:nbn:se:liu:diva-91319 


\section{Clinical pharmacology of infusion fluids}

\author{
Robert G. Hahn \\ Södertälje Hospital, \\ Södertälje, Sweden; \\ Anaesthesia and \\ Intensive Care, \\ Linköping University, \\ Sweden
}

Fluids are used for intravenous infusion during practically all surgeries, but several different compositions are available on the market.

Crystalloid fluids comprise lactated or acetated Ringer solutions, normal saline, Plasma-Lyte, hypertonic saline, and glucose. They lack allergic properties but are prone to cause peripheral tissue oedema. Their turnover is governed by physiological factors such as dehydration and drug effects.

Colloid fluids include hydroxyethyl starch, albumin, dextran, and gelatin. These fluids have various degrees of allergic properties and do not promote peripheral oedema. Their half-life is usually about hours. Factors increasing the turnover rate are poorly known but might include inflammatory states.

Current debates include the widespread use of normal saline, which should be replaced by Ringer's or Plasma-Lyte in most situations, and the kidney damage associated with the use of starch in septic patients. New studies show that hypertonic saline does not improve survival or neurological damage in prehospital care.

Key words: Ringer solution - hydroxyethyl starch - model, pharmacokinetic, fluids, i. v.
Infusion fluids may be regarded as drugs when used during surgery. Their therapeutic effects are strongly related to the administered volume, but fluids of the colloid type may also improve the microcirculation and have anti-inflammatory properties.

Ringer's solutions consist of sterile water to which electrolytes have been added. The fluid does not contain buffering bicarbonate ions, but either lactate or acetate, which are metabolized to bicarbonate. Lactated and acetated Ringer's solutions have quite similar kinetic profiles but acetate is more rapidly metabolized to bicarbonate.

Correspondence to: Robert G. Hahn, Section for Anesthesia, Faculty of Health Sciences, Linköping University,

58185 Linköping, Sweden. E-mail: r.hahn@telia.com
The fluids distribute from the plasma to the interstitial fluid space with a half-life of approximately $8 \mathrm{~min}$, which implies that the plasma volume expansion from Ringer's solution is much greater than usually anticipated. An infusion that lasts for 10 min expands the plasma volume by $75 \%$ of the infused volume, and infusion lasting for $20 \mathrm{~min}$ by $60 \%$ and a $30-$ min infusion by $50 \%$ of the infused volume. Not until distribution is complete four distribution half-lives after the end of an infusion (32 $\mathrm{min}$ ) is the commonly cited plasma volume expansion by $25-30 \%$ of the infused volume reached (1). Hence, Ringer's has an "efficiency" that markedly exceeds $25-30 \%$ as long as the infusion is continued, which is the case during anaesthesia and surgery (Figure). 


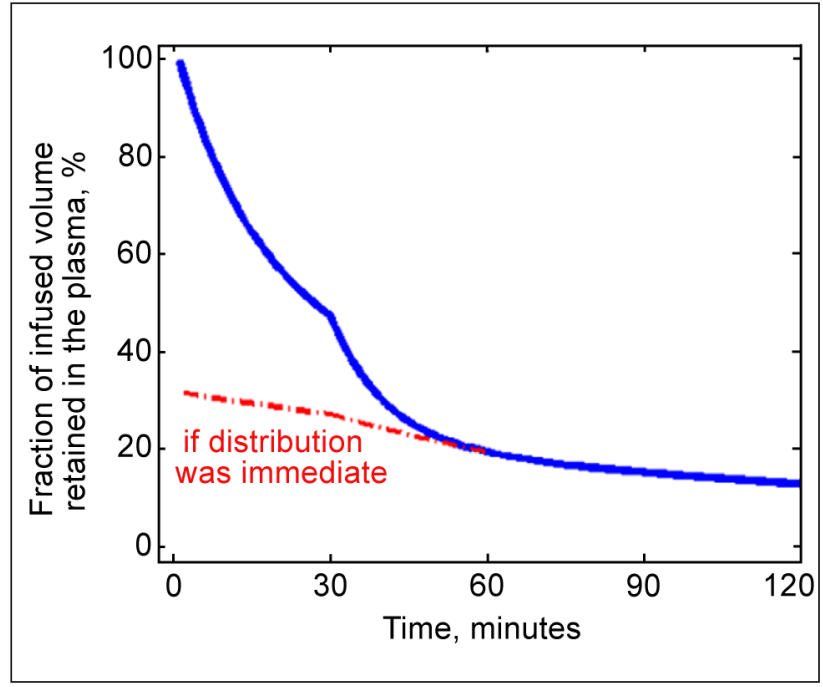

Figure. The plasma volume efficacy of a 30-min infusion of Ringer's acetate.

Illustration of the importance of distribution

Elimination occurs by voiding. In conscious volunteers, the elimination half-life is $15-25$ minutes. However, the half-life is prolonged to $>40$ minutes by dehydration, hypovolaema, pregnancy, and by general anaesthesia per se. The half-life is further prolonged if general anaesthesia is combined with surgery. Of the studied operations, laparoscopy is associated with the longest elimination half-life (>100 minutes). The mechanisms responsible for the poor elimination during anaesthesia and surgery are not known in detail, but increased renin activity (probably due to renal hypo-perfusion) is part of the phenomenon. The urinary excretion becomes more "normal" by esmolol, which decreases the renin excretion (2).

The Ringer's solutions have no allergic potential. They exert a slight procoagulant effect up to haemodilution levels of 20-30\%. More pronounced haemodilution has an anticoagulant effect due to dilution of the plasma protein concentration.

Volunteers receiving $2 \mathrm{~L}$ over 15 min report dyspnoea and headache. Infusing 10 litres of lactated Ringer's during the day of surgery is associated with a risk of potentially fatal pulmonary oedema (3).

Normal saline is still widely used in some countries, but should be abandoned due to the tendency to cause metabolic acidosis and decreased glomerular filtration rate. Hence, normal saline increases breathing in awake subjects and has a longer elimination half-life than the Ringer solutions. Normal saline might still be used in children who have a greater tendency than adults to develop postoperative hyponatraemia.

Plasma-Lyte is an old composition that has only recently been marketed in many European countries. It can be regarded as a slight improvement of Ringer's acetate with its osmolality of $295 \mathrm{mosmol} / \mathrm{kg}$ and sodium content of $140 \mathrm{mmol} / \mathrm{L}$.

Hypertonic saline in strengths of 3\% and 7.5\% is used to treat hyponatraemia, brain oedema in head traumas, and as a plasma volume expander in the prehospital setting. Multicenter trials in the US and Canada have recently demonstrated lack of benefit from prehospital use of $7.5 \%$ sodium chloride with and without dextran $(4,5)$.

Glucose (dextrose) solutions are used to provide water to compensate for evaporation, i. e. water derived from all body fluid compartments. The fluid also provides calories for metabolism, and it is usually given to prevent blunt starvation. However, three litres of $5 \%$ glucose provide $600 \mathrm{kcal}$. Glucose solutions are used in the postoperative setting but rarely during surgery due to risks of hyperglycaemia, hyponatraemia and the fact that an oxygen debt more easily results in brain damage if the plasma glucose level is raised.

Hydroxyethyl starches (HES) are polysaccharides prepared from plants and intended for plasma volume expansion. HES solutions are described by the average molecular weight, degree of substitution, and C2/C6 ratio. For example, the product Voluven, manufactured by Fresenius-Kabi, is denoted HES 130/0.4/9:1. These data determine the characteristics of the solution. The degree of substitution is important to the half-life, while a large molecular size is associated with an increased risk of allergic adverse effects and haemorrhagic complications.

HES distributes quickly over the plasma volume. Most preparations are manufactured to expand the plasma volume with the same amount as that infused. Elimination occurs by direct renal excretion (smallest molecules) and renal excretion after enzymatic cleavage (larger molecules). HES is also the subject of phagocytosis in the reticulo-endothelial system, where the molecules can remain for a long time (years).

Pharmacokinetics has been studied based on measurement of the disappearance of the HES molecules in amount/volume body fluid, which might not correspond exactly to their volume ef- 
fect. However, the elimination half-life of HES 130/0.4 volume seems to be 130 minutes. HES have a maximum daily dose due to an inherent risk of coagulopathy. The highest recommended volume of Voluven is 3.5 litres per $24 \mathrm{hrs}$ in an adult male, while less volume is allowed for starches of higher molecular weight. HES should be avoided in septic patients because it is followed by more impairment of kidney function than gelatin and Ringer's $(6,7)$.

Albumin is manufactured from blood donors and has a long history as a plasma volume expander. In the plasma, albumin exerts $80 \%$ of the oncotic pressure. Albumin 5\% expands plasma volume by $80 \%$ of the infused volume. The plasma concentration is increased by $10 \%$ by an infusion of $10 \mathrm{ml} / \mathrm{kg}$, which is maintained for at least 8 hours. A concomitant reduction of the plasma volume expansion occurs (half-life 2-2.5 hours) (8). Special conditions where albumin is often used include burns and nephritis. Direct adverse effects, such as allergy and coagulation disturbances, are few.

Dextrans are polysaccharides synthesized by bacteria. These macromolecules serve as colloids in the bloodstream. Marketed solutions have an average molecular weight of $40 \mathrm{kD}$ or $70 \mathrm{kD}$ and concentrations vary between $3 \%$ and $10 \%$. Halflives are 4-5 hours (dextran 70) and 2 hours (dextran 40). There is a risk of anaphylaxis of potentially greater severity than to other colloids. Dextran is used for plasma volume expansion, to improve microcirculatory flow, and to prevent thromboembolism.

Gelatin contains polypeptides prepared from animals. The molecular weight averages $30 \mathrm{kD}$. The molecules become eliminated by renal excretion, and the volume expansion is of short duration (2 hours). Anaphylactoid reactions are fairly common $(0.35 \%)$ but rarely severe, and the effect of gelatin on coagulation is slight. The risk of spreading "mad cow's disease" necessitates careful heating before sale. There are two gelatin solutions on the market. Hemaccel contains 3.5\% gelatin prepared from animal collagen. Gelofusine is plasmion-succinylated gelatin mixed in $0.9 \%$ saline.

Received 2 July 2012 Accepted 1 August 2012

\section{References}

1. Hahn RG. Volume kinetics of infusion fluids. Anesthesiology. 2010; 113: 470-81.

2. Li YH, Zhu HB, Zheng X, Chen HJ, Shao L, Hahn RG. Low doses of esmolol and phenylephrine act as diuretics during intravenous anesthesia. Crit Care. 2012; 16(1): R18.

3. Arieff AI. Fatal postoperative pulmonary edema: pathogenesis and literature review. Chest. 1999; 115: 1371-7.

4. Bulger EM, May S, Brasel KJ, Schrieber M, Kerby JD, Tisherman SA, et al. Out-of-hospital hypertonic resuscitation following severe traumatic brain injury: a randomized controlled trial. JAMA. 2010; 304: 1455-564.

5. Bulger EM, May S, Kerby JD, Emerson S, Stiell IG, Schrieber MA, et al. Out-of-hospital hypertonic resuscitation following traumatic hypovolemic shock: a randomized, placebo controlled trial. Ann Surg. 2011; 253: 431-41.

6. Schortgen F, Lacherade JC, Bruneel F, Cattaneo I, Hemery F, Lamaire F, et al. Effects of hydroxyethyl starch and gelatin on renal function in severe sepsis: a multicentre randomised study. Lancet. 2001; 357: 911-6.

7. Perner A, Haase N, Guttormsen AB, Tenhunen J, Klemenzson G, Aneman A, et al. Hydroxyethyl starch 130/0.4 versus Ringer's acetate in severe sepsis. N Engl J Med. In press July 2012.

8. Hedin A, Hahn RG. Volume expansion and plasma protein clearance during intravenous infusion of 5\% albumin and autologous plasma. Clin Sci. 2005; 106: 217-24.

\section{Robert G. Hahn}

\section{KLINIKINĖ INFUZINIŲ SKYSČIŲ FARMAKOLOGIJA}

\section{Santrauka}

Operacijų metu naudojami infuziniai skysčiai gali atlikti ir vaistų funkciją. Koloidiniai skysčiai gali pagerinti mikrocirkuliaciją, pasižymi priešuždegiminèmis savybèmis. Jų terapinis poveikis labai priklauso nuo paskirto tūrio.

Raktažodžiai: klinikinè farmakologija, infuziniai skysčiai, terapinis poveikis, koloidiniai skysčiai 